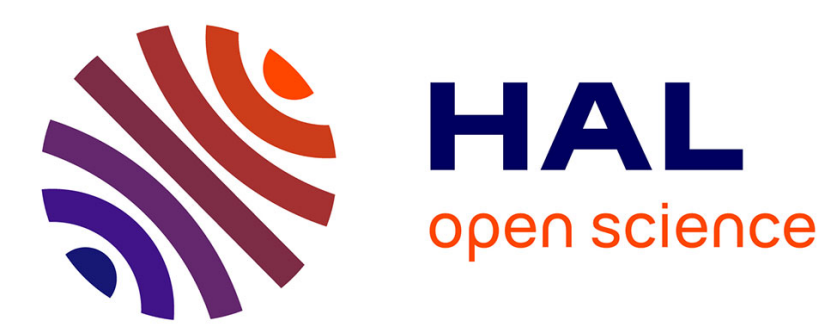

\title{
Identification of Tropilaelaps mites (Acari, Laelapidae) infesting Apis mellifera in China
}

Qi Luo, Ting Zhou, Qiang Wang, Ping Dai, Yan Wu, Huai Song

\section{To cite this version:}

Qi Luo, Ting Zhou, Qiang Wang, Ping Dai, Yan Wu, et al.. Identification of Tropilaelaps mites (Acari, Laelapidae) infesting Apis mellifera in China. Apidologie, 2011, 42 (4), pp.485-498. 10.1007/s13592011-0028-6 . hal-01003559

\section{HAL Id: hal-01003559 \\ https://hal.science/hal-01003559}

Submitted on 1 Jan 2011

HAL is a multi-disciplinary open access archive for the deposit and dissemination of scientific research documents, whether they are published or not. The documents may come from teaching and research institutions in France or abroad, or from public or private research centers.
L'archive ouverte pluridisciplinaire HAL, est destinée au dépôt et à la diffusion de documents scientifiques de niveau recherche, publiés ou non, émanant des établissements d'enseignement et de recherche français ou étrangers, des laboratoires publics ou privés. 


\title{
Identification of Tropilaelaps mites (Acari, Laelapidae) infesting Apis mellifera in China
}

\author{
Qi Hua Luo ${ }^{1,2}$, Ting Zhou ${ }^{1,2}$, Qiang $\mathrm{WANG}^{1,2}$, Ping Li DAI ${ }^{1,2}$, Yan Yan $\mathrm{Wu}^{1,2}$, \\ and Huai Lei SonG ${ }^{1,2}$ \\ ${ }^{1}$ Institute of Apicultural Research, Chinese Academy of Agricultural Science, Xiangshan Road, Beijing 100093, \\ People's Republic of China \\ ${ }^{2}$ Key Laboratory of Pollinating Insect Biology, Ministry of Agriculture, Beijing 100093, China
}

Received 28 December 2009 - Revised 1 August 2010 - Accepted 17 August 2010

\begin{abstract}
Tropilaelaps mite samples were collected from 72 locations in 25 provinces throughout China. The mitochondrial DNA cox 1 and ribosomal ITS1-5.8S-ITS2 fragments of Tropilaelaps mites were surveyed for sequence variation or the presence or absence of specific restriction sites that differentiate four species of Tropilaelaps mite (Tropilaelaps clareae, Tropilaelaps mercedesae, Tropilaelaps koenigerum, and Tropilaelaps thaii). Based on these identified diagnostic characters, all samples in this study corresponded to T. mercedesae, which has been mistaken for T. clareae until now. None of the other Tropilaelaps species were found infesting Apis mellifera in China. A total of 73 coxl haplotypes and 104 ITS1-5.8S-ITS2 haplotypes were discovered in this study. Haplotype analysis revealed that there is no association between geographic distance and genetic distance among populations. The results of the present study clarified the taxonomic status and biogeography of Tropilaelaps mites in China, and should have implications for the control and bee quarantine efforts in China.
\end{abstract}

\section{Tropilaelaps mercedesae / identification / Apis mellifera / mtDNA / cox1 / ITS1-5.8S-ITS2 / China}

\section{INTRODUCTION}

Mites of the genus Tropilaelaps are ectoparasites of honeybees Apis native to Asia (Delfinado and Baker 1961; Laigo and Morse 1968). The primary host of Tropilaelaps mites was recognized as the "giant" honeybee, Apis dorsata (Laigo and Morse 1968; Anderson and Morgan 2007), but they are able to infest a wide spectrum of honeybee species raging from Apis mellifera, Apis cerana, Apis dorsata, Apis florae and Apis laboriosa (Bailey and Ball 1991; Schmid-Hempel 1998). However, Tropilaelaps mites appear to be particularly problematic in $A$. mellifera (Burgett et al. 1983; de Jong et al. 1982; Laigo and Morse 1969). Similar to Varroa destructor Anderson and Trueman (Acari: Varroaidae), Tropilaelaps mites

Corresponding author: T. Zhou, ztapis@263.net Manuscript editor: Marina Meixner infect brood, suck haemolymoph, and can cause brood malformation, death of individual bees, and subsequent colony decline or absconding.

At least four species of Tropilaelaps have been recognized, namely Tropilaelaps clareae Delfinado and Baker, Tropilaelaps mercedesae Anderson and Morgan, Tropilaelaps koenigerum Delfinado-Baker and Baker and Tropilaelaps thaii Anderson and Morgan. T. clareae is a parasite of the native honey bee Apis dorsata breviligula and is also a parasite of the introduced honey bee A. mellifera in the Philippines and the native honey bee species Apis dorsata binghami on the Sulawesi Island in Indonesia. T. mercedesae, which has been mistaken as $T$. clareae until now, together with T. koenigerum, parasitizes the native Apis dorsata dorsata in mainland Asia and Indonesia (except the Sulawesi Island). T. mercedesae is 
also a parasite of $A$. mellifera in these and surrounding regions and, together with another species, T. thaii, also parasitises A. laboriosa in mountainous Himalayan regions (Anderson and Morgan 2007).

In China, Tropilaelaps mites are serious ectoparasites of $A$. mellifera (Zeng 2003; Luo et al. 2008), but the true identity of Tropilaelaps mites infesting $A$. mellifera has been poorly studied. Initially, the mites detected on $A$. mellifera in China have been thought to be $T$. clareae (Woyke 1994). But recently two samples from A. mellifera and one sample from $A$. dorsata dorsata in China were identified as $T$. mercedesae by Anderson and Morgan (2007). This study suggested that the $T$. mercedesae has been observed in A. mellifera and A. dorsata in China, but it is still unclear how many species of Tropilaelaps mites occur in China and whether $A$. mellifera is parasitized by more than one species of Tropilaelaps mites.

Morphological studies of Tropilaelaps species were reported by Anderson and Morgan (2007), while differentiation of Tropilaelaps mites based principally on morphology is difficult and requires taxonomical skills. More recently, nuclear ribosomal DNA (rDNA) has been widely used to differentiate closely related organisms, particularly at interspecific level (Hillis and Davis 1986; Hillis and Dixon 1991; Odorico and Miller 1997). Mitochondrial DNA (mtDNA) has also been widely employed in phylogenetic studies of animals, because it evolves much more rapidly than nuclear DNA, resulting in the accumulation of differences between closely related species (Brown et al. 1979; Moore 1995; Mindell et al. 1997).

In this study, we surveyed samples of Tropilaelaps mites for sequence variation and diagnostic restriction sites in the mtDNA coxl and nuclear rDNA ITS1-5.8S-ITS2 regions, because a previous study (Anderson and Morgan 2007) has shown that these genetic markers were useful in distinguishing four species of Tropilaelaps mites: T. clareae, T. mercedesae, T. koenigerum, and T. thaii. We also analyzed the genetic variation and geographic distribution of cox1 and ITS1-5.8S-ITS2 haplotypes.

\section{MATERIALS AND METHODS}

\subsection{Sampling and DNA extraction}

Samples of adult Tropilaelaps mites were collected from 72 different locations in 25 provinces throughout China in 2007, 2008, and 2009. The locations and collection details of the Tropilaelaps mites examined are described in Table I and shown in Figure 1, the geographic coordinates for the sampling locations are provided in Table II. Mites were collected alive from the capped worker or drone brood cells, and some mites were also collected from the hive bottom boards within $24 \mathrm{~h}$ following the placement of plastic strips impregnated with acaricide (Apistan) between brood frames. All mites were killed and preliminarily identified based on morphology according to Anderson and Morgan (2007). Samples were preserved in absolute ethanol and kept at $-20^{\circ} \mathrm{C}$ until laboratory processing.

Total DNA was extracted from each mite following the procedure of Garnery et al. (1993). A total of 210 mites were subjected to both cox1 and ITS1-5.8S-ITS2 sequence analyses, and additional 429 mites were used for analysis by polymerase chain reaction (PCR)restriction fragment length polymorphism analysis.

\subsection{PCR amplification and sequencing of cox 1 and ITS1-5.8S-ITS2}

The coxl region of the mtDNA was amplified by PCR (Saiki 1990) using the following thermal profile: $94^{\circ} \mathrm{C}$ for $2 \mathrm{~min}$, followed by 35 cycles of $94^{\circ} \mathrm{C}$ for $30 \mathrm{~s}, 47^{\circ} \mathrm{C}$ for $30 \mathrm{~s}, 72^{\circ} \mathrm{C}$ for $30 \mathrm{~s}$, and a final extension of $10 \mathrm{~min}$ at $72^{\circ} \mathrm{C}$. The ITS1-5.8S-ITS2 region was amplified following the same PCR conditions with the exception of annealing temperature which was $54^{\circ} \mathrm{C}$. The reaction volume of $50 \mu \mathrm{L}$ contained $50 \mathrm{ng}$ genomic DNA, $1.0 \mu \mathrm{mol} / \mathrm{L}$ of each primer, $500 \mu \mathrm{mol} / \mathrm{L}$ of each dATP, dGTP, dTTP, and dCTP, and 1.5 units of Takara Taq polymerase. Reactions were buffered by addition of the PCR buffer (Takara Shuzo Co., Ltd.) containing $1.75 \mathrm{mmol} / \mathrm{L} \mathrm{MgCl}_{2}$. The primers for amplifying coxl and ITS1-5.8S-ITS2 were described by Anderson et al. (1998) and White et al. (1990) respectively.

The PCR products were purified and cloned into the T-Easy vector (Promega). The recombinant plasmid was used to transform the competent 


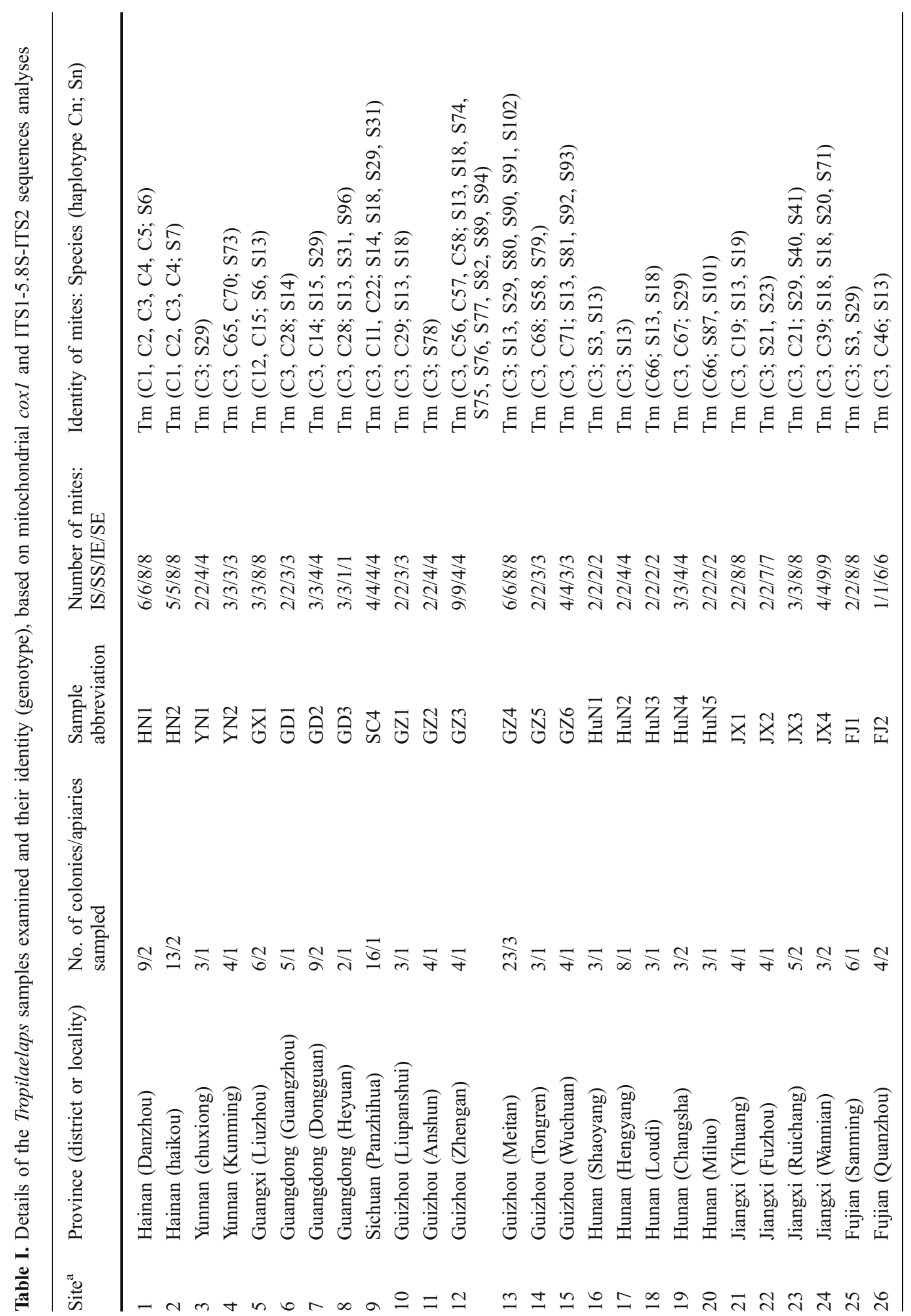




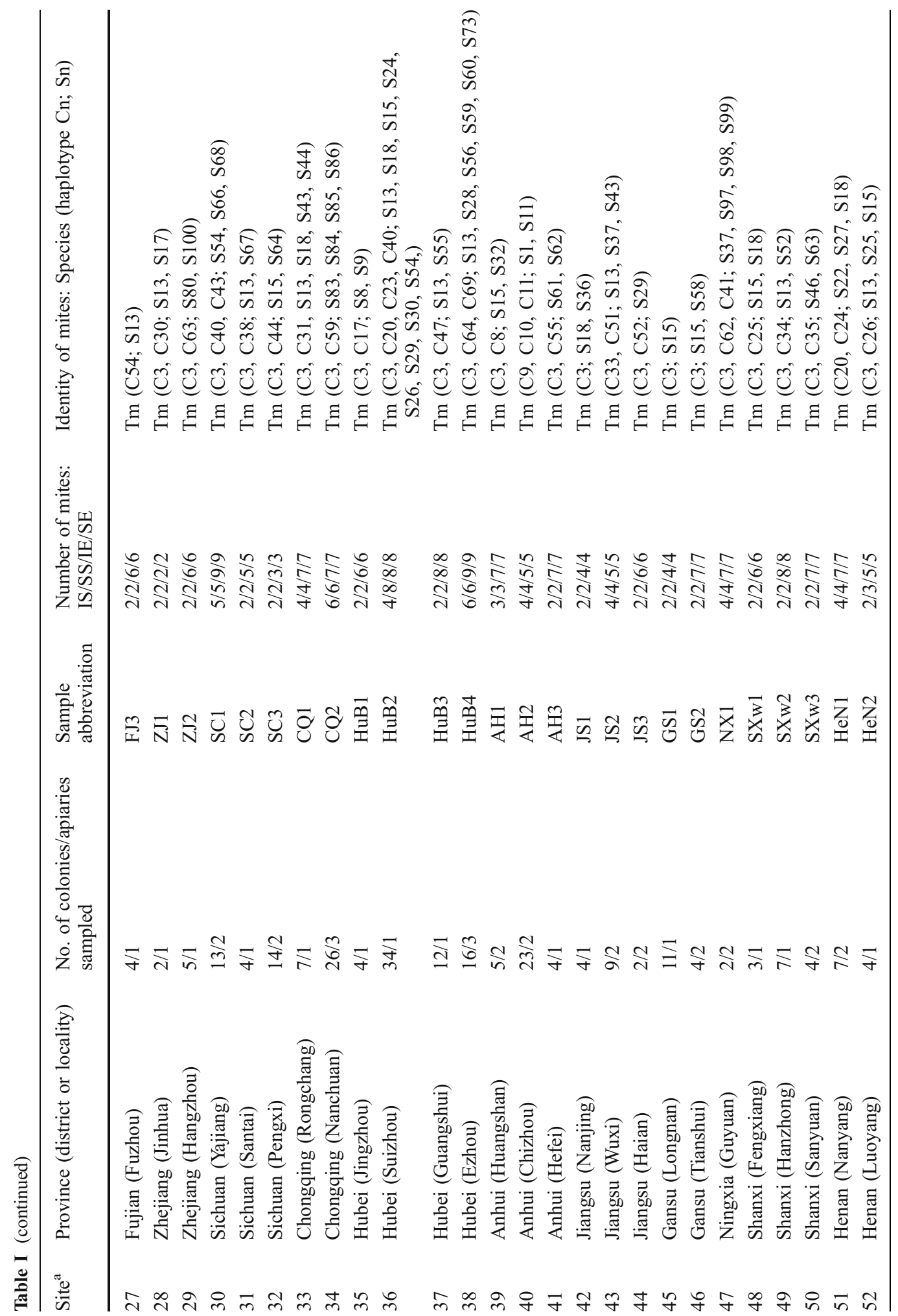




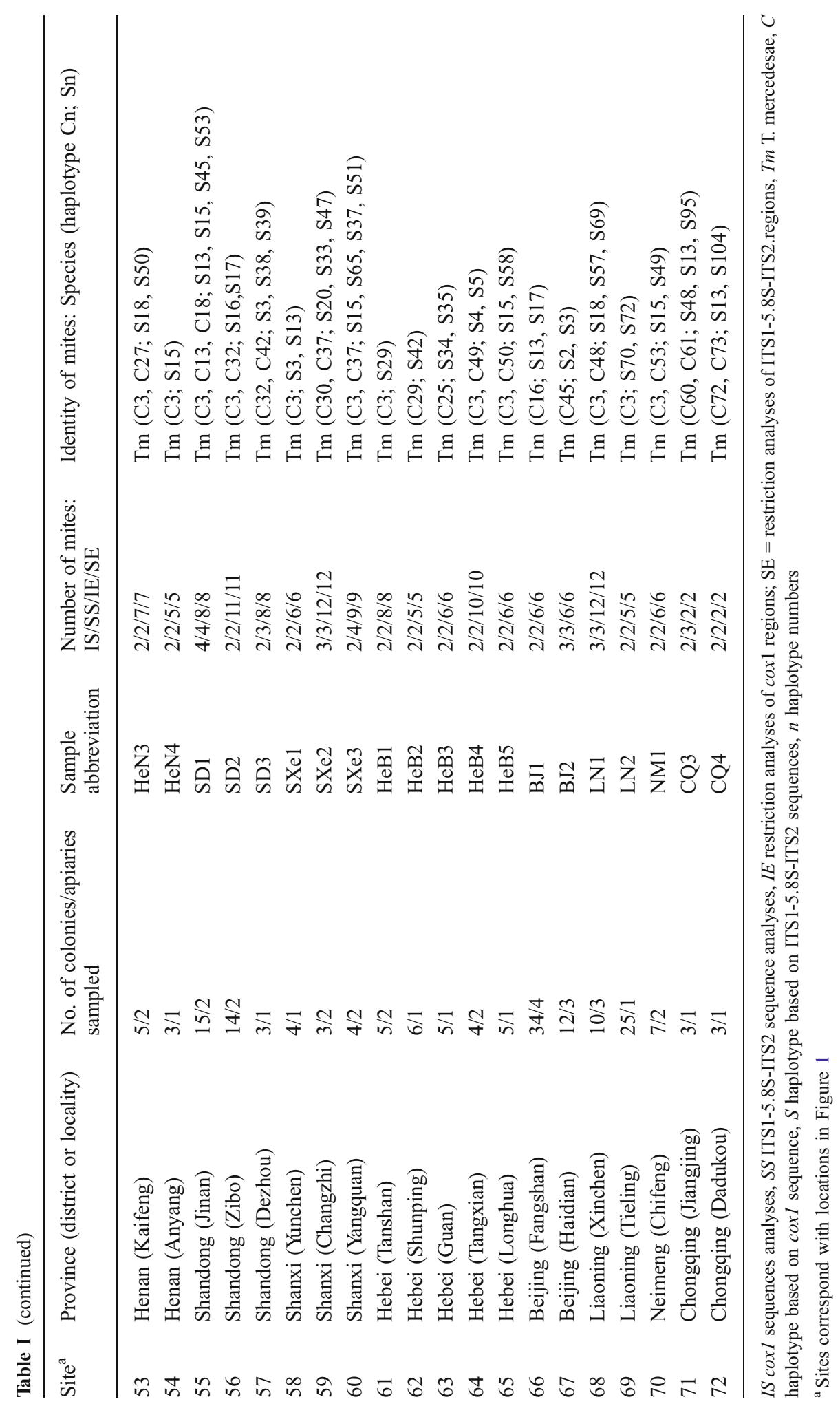




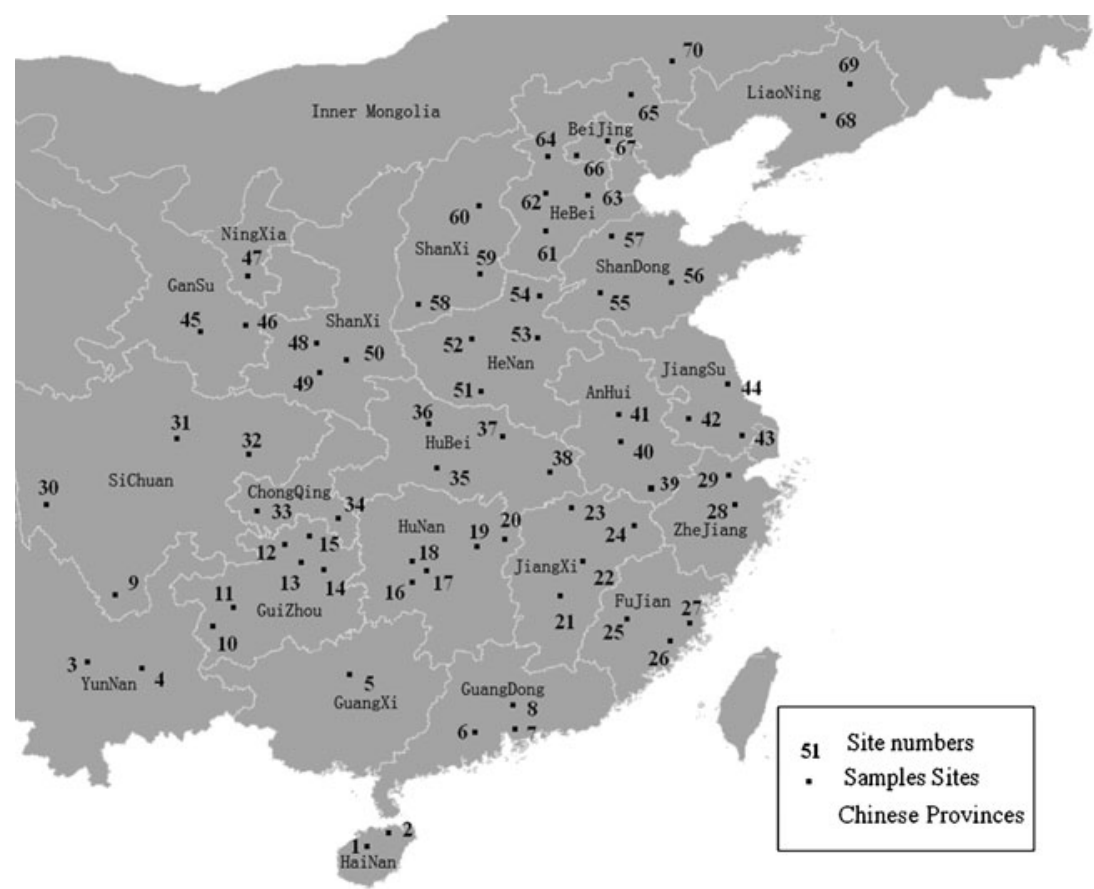

Figure 1. Map of China showing sampling locations $(1-70)$ of mite specimens used in this study. Names of the localities are given in Table I.

Escherichia coli DH-5a cells. Positive clones were screened and subjected to sequencing using ABI-377 (Applied Biosystems)

\subsection{Restriction analysis of amplified cox1 and ITS}

Species-specific markers were used as described by Anderson and Morgan (2007) to confirm the identity of Tropilaelaps mites of China. Coxl fragments were digested with restriction enzymes FauI, BsrI, Bst YI, SwaI, and ITS1-5.8S-ITS2 with RsaI. The digests were analyzed by electrophoresis through $2.0 \%$ MetaPhor agarose gels (FMC) and visualized under a UV transilluminator after staining with ethidium bromide.

\subsection{Data analysis}

The nucleotide sequences were analyzed using BLAST (Altschul et al. 1990) and Clustal W
(Thompson et al. 1994). The genetic diversity of the haplotypes $(H)$ and nucleotides $(P)$ was calculated by using the DnaSP program (Rozas et al. 2003). Phylogenetic relationships among haplotypes were estimated by using the MEGA program (Kumar et al. 2004), based on the neighbor-joining (NJ) algorithm and the Tamura-Nei genetic distance model. Bootstrap support was calculated by means of 1,000 replicates, with $70 \%$ support considered wellsupported (Hillis and Bull 1993; Efron et al. 1996). In order to confirm the identity of Tropilaelaps mites in China, the mtDNA coxl haplotypes in this study were compared with those available in previous inquiries, from Thailand, EF025445.1 (T. mercedesae); Vietnam, EF025452.1 (T. thaii); Mindoro, EF025464.1 (T. clareae); Sumatra, EF025451.1 ( $T$. koenigerum); and the ITS1-5.8S-ITS2 haplotypes were compared with those from Sri Lanka, EF025472.1 (T. mercedesae); Thailand, AF544013.1 (T. clareae); Vietnam, EF025477.1 (T. thaii); 
Table II. Geographic coordinates for sampling locations of mite specimens used in this study

\begin{tabular}{|c|c|c|c|c|}
\hline Site $^{\mathrm{a}}$ & Province & District or locality & Longitude & Latitude \\
\hline 1 & Hainan & Danzhou & $109.58313 \mathrm{E}$ & $19.526142 \mathrm{~N}$ \\
\hline 2 & Hainan & Haikou & $110.360413 \mathrm{E}$ & $20.024968 \mathrm{~N}$ \\
\hline 3 & Yuannan & Chuxiong & $101.539764 \mathrm{E}$ & $25.055745 \mathrm{~N}$ \\
\hline 4 & Yuannan & Kunming & $102.757874 \mathrm{E}$ & $25.073783 \mathrm{~N}$ \\
\hline 5 & Guangxi & Liuzhou & $109.416275 \mathrm{E}$ & $24.317691 \mathrm{~N}$ \\
\hline 6 & Guangdong & Guangzhou & $113.26355 \mathrm{E}$ & $23.216107 \mathrm{~N}$ \\
\hline 7 & Guangdong & Dongguan & $113.774414 \mathrm{E}$ & $23.074678 \mathrm{~N}$ \\
\hline 8 & Guangdong & Heyuan & $114.686279 \mathrm{E}$ & $23.750154 \mathrm{~N}$ \\
\hline 9 & Sichuan & Panzhihua & $101.724472 \mathrm{E}$ & $26.581159 \mathrm{~N}$ \\
\hline 10 & Guizhou & Liupanshui & $104.82811 \mathrm{E}$ & $26.594053 \mathrm{~N}$ \\
\hline 11 & Guizhou & Anshun & $105.941849 \mathrm{E}$ & $26.256781 \mathrm{~N}$ \\
\hline 12 & Guizhou & Zhengan & $107.438049 \mathrm{E}$ & $28.557988 \mathrm{~N}$ \\
\hline 13 & Guizhou & Meitan & $107.471008 \mathrm{E}$ & $27.749177 \mathrm{~N}$ \\
\hline 14 & Guizhou & Tongren & $109.186249 \mathrm{E}$ & $27.720005 \mathrm{~N}$ \\
\hline 15 & Guizhou & Wuchuan & 107.892609 E & $28.533862 \mathrm{~N}$ \\
\hline 16 & Hunan & Shaoyang & $111.460419 \mathrm{E}$ & $27.318705 \mathrm{~N}$ \\
\hline 17 & Hunan & Hengyang & $112.372284 \mathrm{E}$ & $26.96859 \mathrm{~N}$ \\
\hline 18 & Hunan & Loudi & $111.994972 \mathrm{E}$ & $27.699944 \mathrm{~N}$ \\
\hline 19 & Hunan & Changsha & $113.080902 \mathrm{E}$ & $28.253586 \mathrm{~N}$ \\
\hline 20 & Hunan & Miluo & $113.080902 \mathrm{E}$ & $28.881957 \mathrm{~N}$ \\
\hline 21 & Jiangxi & Yihuang & $116.216125 \mathrm{E}$ & $27.522887 \mathrm{~N}$ \\
\hline 22 & Jiangxi & Fuzhou & 116.39019 E & $27.998342 \mathrm{~N}$ \\
\hline 23 & Jiangxi & Ruichang & $115.666466 \mathrm{E}$ & $29.673735 \mathrm{~N}$ \\
\hline 24 & Jiangxi & Wannian & $117.068939 \mathrm{E}$ & $28.694804 \mathrm{~N}$ \\
\hline 25 & Fujian & Sanming & $117.641258 \mathrm{E}$ & $26.264478 \mathrm{~N}$ \\
\hline 26 & Fujian & Quanzhou & $118.590546 \mathrm{E}$ & $24.906367 \mathrm{~N}$ \\
\hline 27 & Fujian & Fuzhou & $119.261055 \mathrm{E}$ & $26.079913 \mathrm{~N}$ \\
\hline 28 & Zhejiang & Jinhua & $119.609871 \mathrm{E}$ & $29.100877 \mathrm{~N}$ \\
\hline 29 & Zhejiang & Hangzhou & $120.070953 \mathrm{E}$ & $30.420256 \mathrm{~N}$ \\
\hline 30 & Sichuan & Yajiang & $101.008301 \mathrm{E}$ & $29.993002 \mathrm{~N}$ \\
\hline 31 & Sichuan & Santai & $105.095215 \mathrm{E}$ & $31.088222 \mathrm{~N}$ \\
\hline 32 & Sichuan & Pengxi & $105.718689 \mathrm{E}$ & $30.772519 \mathrm{~N}$ \\
\hline 33 & Chongqing & Rongchang & $105.593033 \mathrm{E}$ & $29.391748 \mathrm{~N}$ \\
\hline 34 & Chongqing & Nanchuan & $107.09198 \mathrm{E}$ & $29.152161 \mathrm{~N}$ \\
\hline 35 & Hubei & Jingzhou & $112.17762 \mathrm{E}$ & $30.369247 \mathrm{~N}$ \\
\hline 36 & Hubei & Suizhou & $113.384743 \mathrm{E}$ & $31.658934 \mathrm{~N}$ \\
\hline 37 & Hubei & Guangshui & $113.779221 \mathrm{E}$ & $31.545186 \mathrm{~N}$ \\
\hline 38 & Hubei & Ezhou & $114.88678 \mathrm{E}$ & $30.409005 \mathrm{~N}$ \\
\hline 39 & Anhui & Huangshan & $118.405838 \mathrm{E}$ & $29.722048 \mathrm{~N}$ \\
\hline 40 & Anhui & Chizhou & $117.499294 \mathrm{E}$ & $30.681916 \mathrm{~N}$ \\
\hline 41 & Anhui & Hefei & $117.310638 \mathrm{E}$ & $31.87989 \mathrm{~N}$ \\
\hline 42 & Jiangsu & Nanjing & $119.083557 \mathrm{E}$ & $32.056973 \mathrm{~N}$ \\
\hline
\end{tabular}


Table II (continued)

\begin{tabular}{|c|c|c|c|c|}
\hline Site $^{\mathrm{a}}$ & Province & District or locality & Longitude & Latitude \\
\hline 43 & Jiangsu & Wuxi & $120.274887 \mathrm{E}$ & $31.589064 \mathrm{~N}$ \\
\hline 44 & Jiangsu & Haian & $120.480194 \mathrm{E}$ & $32.552022 \mathrm{~N}$ \\
\hline 45 & Gansu & Longnan & $104.932995 \mathrm{E}$ & $33.406081 \mathrm{~N}$ \\
\hline 46 & Gansu & Tianshui & $105.713882 \mathrm{E}$ & $34.575278 \mathrm{~N}$ \\
\hline 47 & Ningxia & Guyuan & $106.2323 \mathrm{E}$ & $36.02439 \mathrm{~N}$ \\
\hline 48 & Shanxi & Fengxiang & 107.378311 E & $34.532581 \mathrm{~N}$ \\
\hline 49 & Shanxi & Hanzhong & $107.058334 \mathrm{E}$ & $33.076008 \mathrm{~N}$ \\
\hline 50 & Shanxi & Sanyuan & $108.927383 \mathrm{E}$ & $34.637163 \mathrm{~N}$ \\
\hline 51 & Henan & Nanyang & $112.508926 \mathrm{E}$ & $33.003481 \mathrm{~N}$ \\
\hline 52 & Henan & Luoyang & $112.48558 \mathrm{E}$ & $34.627558 \mathrm{~N}$ \\
\hline 53 & Henan & Kaifeng & $114.321671 \mathrm{E}$ & $34.760794 \mathrm{~N}$ \\
\hline 54 & Henan & Anyang & $114.349823 \mathrm{E}$ & $36.132329 \mathrm{~N}$ \\
\hline 55 & Shandong & Jinan & $117.000275 \mathrm{E}$ & $36.689896 \mathrm{~N}$ \\
\hline 56 & Shandong & Zibo & $117.92038 \mathrm{E}$ & $36.836218 \mathrm{~N}$ \\
\hline 57 & Shandong & Dezhou & 116.325989 E & $37.507002 \mathrm{~N}$ \\
\hline 58 & Shanxi & Yunchen & $110.965004 \mathrm{E}$ & $35.001878 \mathrm{~N}$ \\
\hline 59 & Shanxi & Changzhi & $113.15609 \mathrm{E}$ & $36.195525 \mathrm{~N}$ \\
\hline 60 & Shanxi & Yangquan & $113.571854 \mathrm{E}$ & $37.884067 \mathrm{~N}$ \\
\hline 61 & Hebei & Tanshan & $118.181305 \mathrm{E}$ & $39.632134 \mathrm{~N}$ \\
\hline 62 & Hebei & Shunping & $115.138092 \mathrm{E}$ & $38.878205 \mathrm{~N}$ \\
\hline 63 & Hebei & Guan & $116.315002 \mathrm{E}$ & $39.452631 \mathrm{~N}$ \\
\hline 64 & Hebei & Tangxian & $114.98291 \mathrm{E}$ & $38.743373 \mathrm{~N}$ \\
\hline 65 & Hebei & Longhua & $117.729492 \mathrm{E}$ & $41.304634 \mathrm{~N}$ \\
\hline 66 & Beijing & Fangshan & $116.146088 \mathrm{E}$ & $39.751017 \mathrm{~N}$ \\
\hline 67 & Beijing & Haidian & $116.201706 \mathrm{E}$ & $40.012628 \mathrm{~N}$ \\
\hline 68 & Liaoning & Xinchen & $120.727386 \mathrm{E}$ & $40.614995 \mathrm{~N}$ \\
\hline 69 & Liaoning & Tieling & $123.812828 \mathrm{E}$ & $42.310577 \mathrm{~N}$ \\
\hline 70 & Neimeng & Chifeng & $118.868637 \mathrm{E}$ & $42.281119 \mathrm{~N}$ \\
\hline 71 & Chongqing & Jiangjing & $106.260452 \mathrm{E}$ & $29.291789 \mathrm{~N}$ \\
\hline 72 & Chongqing & Dadukou & $106.482925 \mathrm{E}$ & $29.486528 \mathrm{~N}$ \\
\hline
\end{tabular}

Lombok-EF025475.1 (T. koenigerum). All of these sequences except AF544013.1 (Tangjingjai et al. 2003) were from Anderson and Morgan (2007).

\section{RESULTS}

All mites in this study were preliminarily identified as T. mercedesae based on morphology according to Anderson and Morgan (2007). The identities of mites were confirmed by their cox1 and ITS sequences or restriction enzyme analyses are summarized in Table I.

\subsection{Analysis of cox 1 sequences}

All of the amplified coxl fragments from Tropilaelaps mite in this study were 538 bp in length, and showed a high level of similarity (97-100\%) to that of T. mercedesae described by Anderson and Morgan (2007), but lower similarity to T. thaii (88\%), T. clareae (88\%), T. 
koenigerum (86\%). There was a difference between all Tropilaelaps mite in the present study and previously reported $T$. mercedesae at the site of 514 bp (Figure 2), they were G:C base pairs instead of T:A base pairs. Alignment of the coxl sequences of Tropilaelaps mite in China were shown in Figure 2 [the GenBank accession no. were HQ533148 (HN5), HQ533149 (JX3), HQ533150(HeB3), HQ533151(SXe2), HQ 533152 (GD 1), HQ5 33153 ( SXw2), HQ533154(YN2), HQ533155(GZ6), HQ533156 (HuB2), HQ533157(GX1), HQ533158(NX1), and HQ533159(LN1)]. Cox1 sequences of $T$. mercedesae in this study exhibited low levels of nucleotide diversity $(P)$ : $0.00396 \pm 0.00018$ (mean \pm standard), while, haplotypic diversity (H) was relatively high: $0.654 \pm 0.044$. A total of 73 haplotypes were found (sites with alignment gaps were considered) from 202 sequenced individuals (eight mites were not successfully amplified), the haplotype C3 being the most frequent $(53.96 \%)$. Haplotype analysis revealed that there was no association between geographic distance and genetic distance among populations, because identical haplotypes have been widely distributed geographically (e.g., C3).

Phylogenetic analyses performed under all three optimality criteria (maximum parsimony, maximum likelihood, and neighbor-joining) produced similar results. Hence, only the NJ analyses are reported here. Branches supported by more than $50 \%$ of the bootstrap replicates were indicated (Figure 3). NJ analysis revealed that all haplotypes in China grouped closely with haplotype from $T$. mercedesae recently described by Anderson and Morgan (2007). Indeed, all of the coxl haplotypes in China and T. mercedesae (data available in GenBank) formed tight, monophyletic clusters supported by high bootstrap values $(99 \%)$. The NJ topology also supported that these mites were separable from the $T$. clareae, T. koenigerum, and T. thaii described by Anderson and Morgan (2007).

\subsection{ITS1-5.8S-ITS2 sequences analysis}

The ITS4 and ITS5 primers amplified a single DNA fragment from each of the mite samples. The sequences were $99 \%$ similar to the ITS1-5.8S-ITS2 sequence of T. mercedesae, 96\% similar to $T$. clareae, $96 \%$ similar to $T$. thaii and $92 \%$ similar to $T$. koenigerum described by Anderson and Morgan (2007). Alignment of the ITS1-5.8S-ITS2 sequences of Tropilaelaps mite in China is shown in Figure 4 [the GenBank accession no. were HQ533160 (CQ1), HQ533161(HuB1), HQ533162(HN1), HQ533163(GZ3), HQ533164(HuN 1), HQ 533165 (SXe3), HQ533166(SXw 1), HQ533167(NM1), HQ533168(ZJ2), HQ533169 (CQ2), HQ533170(HuN1), and HQ533171 (AH2)]. ITS1-5.8S-ITS2 sequences of T. mercedesae in this study exhibited low levels of nucleotide diversity $(P)$ : $0.00479 \pm 0.00057$, while haplotypic diversity $(H)$ was relatively high: $0.8691 \pm 0.020$. A total of 104 haplotypes (sites with alignment gaps were considered) were discovered from 210 sequenced individuals (Table I). Haplotype S13, S15, and S18 were the most frequent $(10.47 \%, 10 \%$, and $8.57 \%$ respectively). Haplotype analysis also revealed that there was no association between geographic distance and genetic distance among populations.

Phylogenetic analysis of the ITS haplotypes resulted in a neighbor-joining tree (Figure 5) that was similar to that based on mitochondrial data (Figure 3). Branches that were supported by more than $50 \%$ of the neighbor-joining bootstrap replicates are indicated. Phylogenetic relationship analysis also revealed that all ITS15.8S-ITS2 haplotypes in this study grouped in one cluster with $T$. mercedesae described by Anderson and Morgan (2007), even though the bootstrap value was only moderately high (72\%). This tree also indicated that Tropilaelaps mites in China were distinct from the T. clareae, T. koenigerum, and T. thaii.

\subsection{Restriction enzyme markers for identifying Tropilaelaps mites}

The particular restriction sites surveyed here were selected because previous studies have shown no variation within each of the four Tropilaelaps species, but reliable differences 

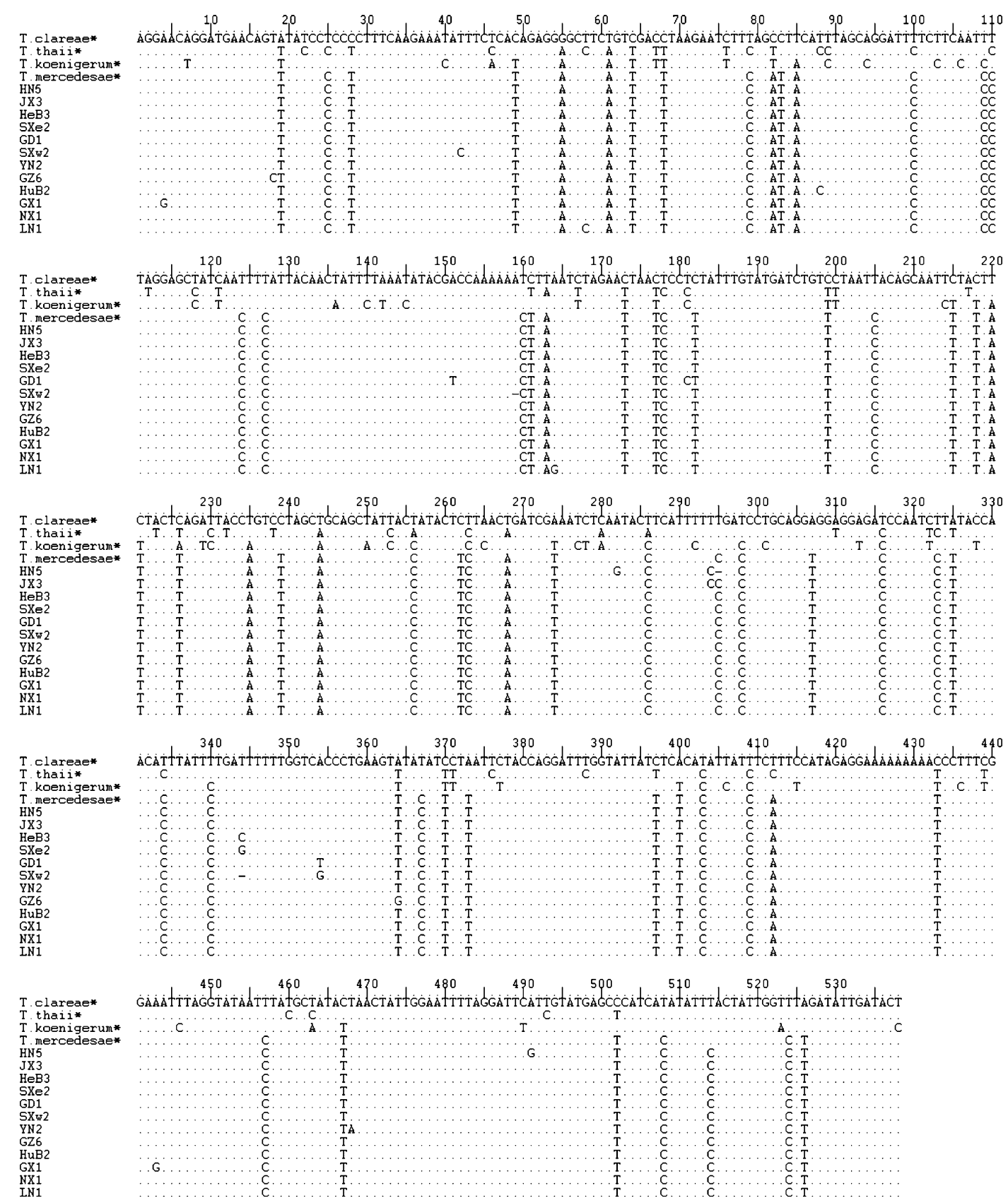

Figure 2. Alignment of mtDNA coxl sequences of representative Tropilaelaps mites in this study. The reference sequences are indicated by an asterisk (*). A dot indicates an identical nucleotide and hyphens refer to insertion/deletion. The GenBank accession no. of sequences in this study were HQ533148 (HN5), HQ533149 (JX3), HQ533150(HeB3), HQ533151 (SXe2), HQ533152 (GD1), HQ533153 (SXw2), HQ533154 (YN2), HQ533155 (GZ6), HQ533156 (HuB2), HQ533157 (GX1), HQ533158 (NX1), and HQ533159 (LN1). 


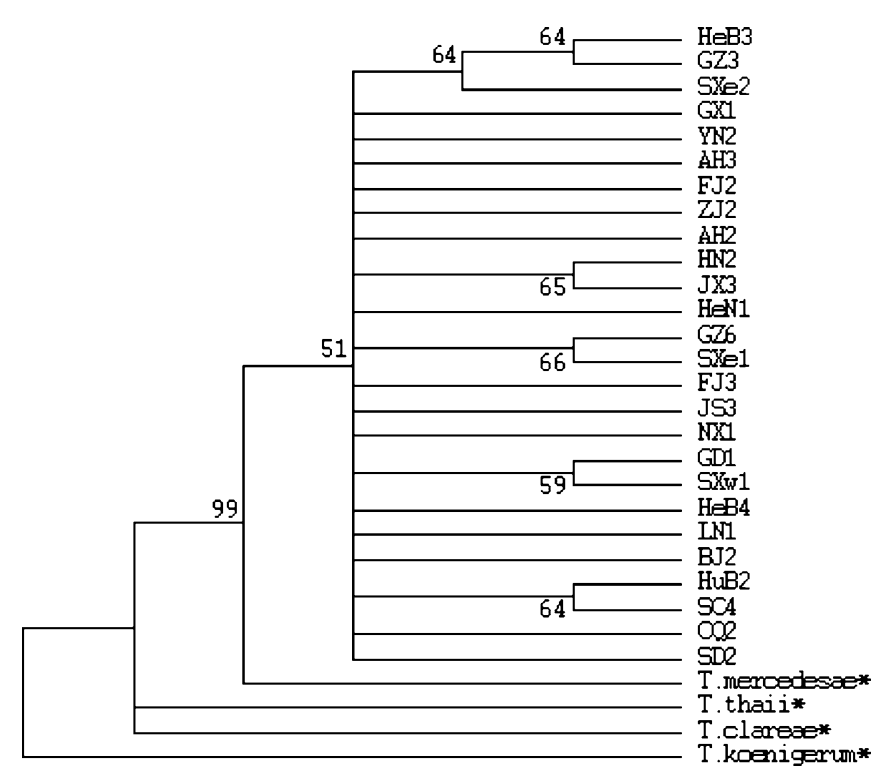

Figure 3. A neighbor-joining phenogram illustrating relationships between representative Tropilaelaps mites in this study and other reference Tropilaelaps species based on mitochondrial coxl sequence. The reference Tropilaelaps species are indicated by an asterisk (*).

among species. Restriction enzyme analyses on 429 mites from each location in this study confirmed that mite samples from different locations were invariant. All samples showed typical restriction patterns of the T. mercedesae: the BsrI site in coxl and the RsaI site in ITS15.8S-ITS2 were present, and the SwaI, FauI, Bst YI sites in coxl was absent.

\section{DISCUSSION}

Based on the sequence variation or specific restriction sites in cox1 and ITS1-5.8S-ITS2 fragments, all Tropilaelaps mites examined in this study were shown to represent $T$. mercedesae, which has been mistaken for $T$. clareae until now. Thus, our results clarify the taxonomic status of Tropilaelaps mites infesting $A$. mellifera in China.

These results confirm a similar finding by Anderson and Morgan (2007). We did not detect T. clareae, T. koenigerum, and T. thaii infesting A. mellifera in China. This may be explained by the fact that none of these mite species has been detected in A. dorsata in China (Anderson and
Morgan 2007), which is the natural host of Tropilaelaps mites. Thus, in China, only the species $T$. mercedesae may have been available to transfer to A. mellifera as an alternate host.

More recently, the health of honeybee is drawing special attention because of reported declines in bee colonies and the "ecosystem services" they provide. This issue has been brought to even more attention by recent devastating losses of honey bees throughout North America (so called, "Colony Collapse Disorder"; Otterstatter and Thomson 2008; vanEngelsdorp et al. 2009); yet, we still have little understanding of the cause(s) of bee declines. Although there were no reports of high losses in China, honeybee health has gained special attention in the past 3 years. Although Tropilaelaps is one of the major threats for the health of $A$. mellifera in Asia, it has received comparatively little scientific interest to date and basic studies are still lacking. Several areas of research should be addressed. For example, given the lack of samples from $A$. dorsata in this study, maybe other Tropilaelaps haplotypes or species await discovery in $A$. 

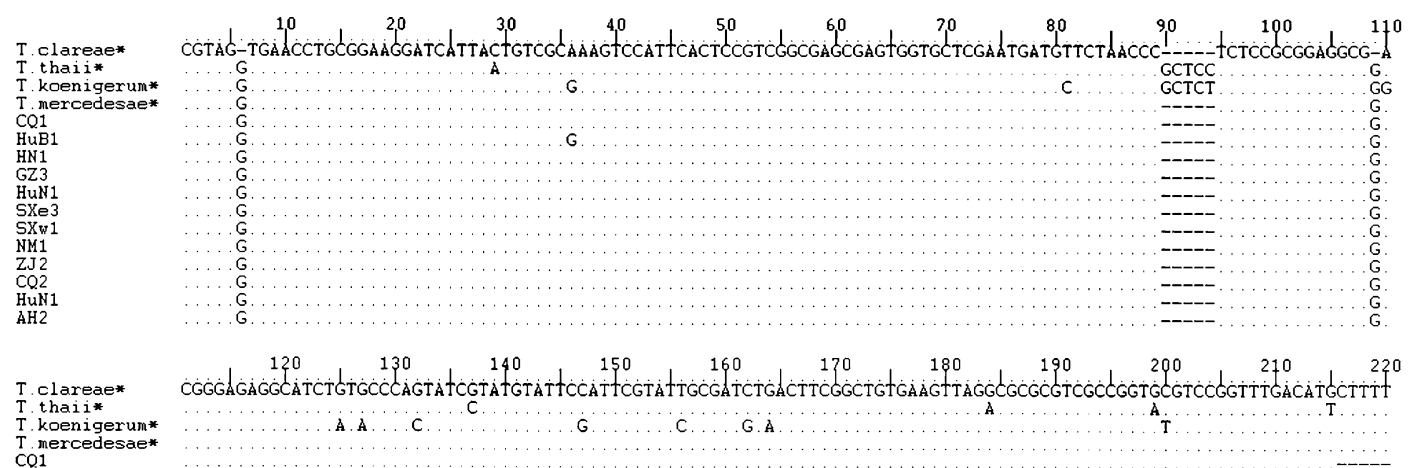
CQ1 HuB1 HN1

HuN1
SXe3

SXv1

ZJ2

CQ2
HuN1

AH2


AGTTGTGAAATTTGTGAGCATTG
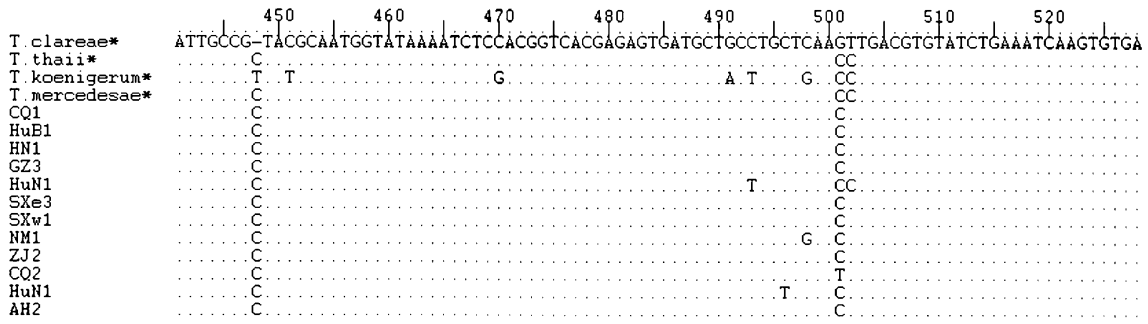

Figure 4. Alignment of ITS1-5.8S-ITS2 sequences of representative Tropilaelaps mites in this study. The reference sequences are indicated by an asterisk (*). A dot indicates an identical nucleotide and hyphens refer to insertion/deletion. The GenBank accession no. of sequences in this study were HQ533160(CQ1), HQ533161 (HuB1), HQ533162(HN1), HQ533163(GZ3), HQ533164(HuN1), HQ533165(SXe3), HQ533166(SXw1), HQ533167(NM1), HQ533168(ZJ2), HQ533169(CQ2), HQ533170(HuN1), and HQ533171(AH2). 


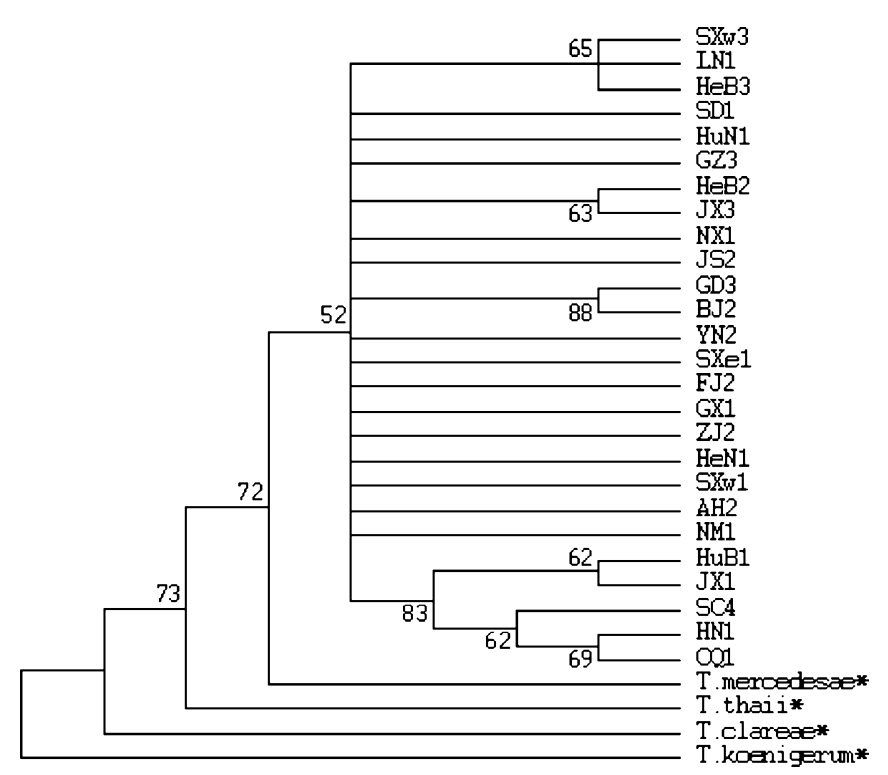

Figure 5. A neighbor-joining phenogram illustrating relationships between representative Tropilaelaps mites in this study and other reference Tropilaelaps species based on ITS1-5.8S-ITS2 sequence. The reference Tropilaelaps species are indicated by an asterisk (*).

dorsata in China. Also, the relationship among Tropilaelaps mites, A. dorsata and A. mellifera is not clear, and how Tropilaelaps actually damages these hosts. Next, we need to determine whether any of these newly described Tropilaelaps species will also cross-infest the endemic domesticated honeybee, A. cerana. Then, epidemiological studies to identify relevant and potentially avoidable exposures are very important. Finally, additional research on in vitro culture of Tropilaelaps mites is needed, although laboratory methods for culturing $T$. clareae were developed by Rath (1991).

\section{ACKNOWLEDGMENTS}

This study was supported by grants from National Natural Science Foundation of China (No. 30871831). We would like to thank the editors and two anonymous referees for detailed comments and suggestions. Thanks are also due to Dr. Jeff Pettis from the USDA-ARS Bee Research Laboratory for comments on the manuscript. Special thanks go to Jun Guo (Institute of Bees Research, Chongqing Academy of Animal Sciences), who have helped us collect samples in this study.
Identification des acariens du genre Tropilaelaps (Acari, Laelapidae) infestant Apis mellifera en Chine.

Tropilaelaps mercedesae / identification / Apis mellifera / Chine / mtDNA / cox1

Die Identifizierung von Tropilaelaps Milben (Acari, Laelapidae) auf Apis mellifera in China

Tropilaelaps mercedesae / Identifizierung / Apis mellifera / mtDNA / cox1 / ITS1-5.8S-ITS2 / China

\section{REFERENCES}

Altschul, S.F., Gish, W., Miller, W., Myers, E.W., Lipman, D.J. (1990) Basic local alignment search tool, J. Mol. Biol. 215, 403-410.

Anderson, D.L., Gibbs, A.J., Gibson, N.L. (1998) Identification and phylogeny of spore-cyst fungi (Ascosphaera spp.) using ribosomal DNA sequences, Mycol. Res. 102, 541-547.

Anderson, D.L., Morgan, M.J. (2007) Genetic and morphological variation of bee-parasitic Tropilaelaps mites (Acari: Laelapidae): new and re-defined species, Exp. Appl. Acarol. 43, 1-24. 
Bailey, L., Ball, B.V. (1991) Honey bee pathology, Academic Press, London.

Brown, W.M., George, M.J., Wilson, A.C. (1979) Rapid evolution of animal mitochondrial DNA, Proc. Natl. Acad. Sci. U.S.A. 76, 1967-1971.

Burgett, M., Akratanakul, P., Morse, R.A. (1983) Tropilaelaps clareae: A parasite of honeybees in South-East Asia, Bee World 64, 25-28.

de Jong, D., Morse, R.A., Eickwort, G.C. (1982) Mite pests of honeybees, Annu. Rev. Entomol. 27, 229-252.

Delfinado, M.D., Baker, E.W. (1961) Tropilaelaps, a new genus of mite from the Philippines (Laelapidae, Acarina), Fieldiana Zool. 44, 53-56.

Efron, B., Halloran, E., Holmes, S. (1996) Bootstrap confidence levels for phylogenetic trees, Proc. Natl. Acad. Sci. U.S.A. 93, 7085-7090.

Garnery, L., Solignac, M., Celebrano, G., Cornuet, J.M. (1993) A simple test using restricted PCR amplified mitochondrial DNA to study the genetic structure of Apis mellifera L., Experientia 49, 1016-1021.

Hillis, D.M., Bull, J.J. (1993) An empirical-test of bootstrapping as a method for assessing confidence in phylogenetic analysis, Syst. Biol. 42, 182-192.

Hillis, D.M., Davis, S.K. (1986) Evolution of ribosomal DNA: fifty million years of recorded history in the frog genus, Rana, Evolution 40, 1275-1288.

Hillis, D.M., Dixon, M.T. (1991) Ribosomal DNA: molecular evolution and phylogenetic inference, Q. Rev. Biol. 66, 411-453.

Kumar, S., Tamura, K., Nei, M. (2004) MEGA3: integrated software for molecular evolutionary genetics analysis and sequence alignment, Brief Bioinform 5, 150-163.

Laigo, F.M., Morse, R.A. (1968) The mite Tropilaelaps clareae in Apis dorsata colonies in the Philippines, Bee World 49, 116-118.

Laigo, F.M., Morse, R.E. (1969) Control of the bee mites Varroa jacobsoni Oudemans and Tropilaelaps clareae Delfinado and Baker with chlorbenzilate, Philippine Entomol. 1, 144-148.

Luo, Q.H., Peng, W.J., An, J.D., Guo, J. (2008) The potential causes of colony collapse disorder (CCD) and its countermeasures in China, Chin. Bull. entomol. 45, 991-995.

Mindell, D.P., Sorenson, M.D., Huddleston, C.J., Miranda, H.C., Knight, A., et al. (1997) Phylogenetic relationships among and within select avian orders based on mitochondrial DNA, in: Mindell D.P. (Ed.), Avian molecular evolution and systematics, Academic Press, New York, pp. 214-217.
Moore, W.S. (1995) Inferring phylogenies from mtDNA variation: Mitochondrial-gene trees versus nucleargene trees, Evolution 49, 718-726.

Odorico, D.M., Miller, D.J. (1997) Variation in the ribosomal internal transcribed spacers and $5.8 \mathrm{~S}$ rDNA among five species of Acropora (Cnidaria; Scleractinia): patterns of variation consistent with reticulate evolution, Mol. Biol. Evol. 14, 465-473.

Otterstatter, M.C., Thomson, J.D. (2008) Does pathogen spillover from commercially reared bumble bees threaten wild pollinators, PLoS ONE 3, e2771.

Rath, W. (1991) The laboratory culture of the mites Varroa jacobsoni and Tropilaelaps clareae, Exp. Appl. Acarol. 10, 289-293.

Rozas, J., Sanchez-DelBarrio, J.C., Messeguer, X., Rozas, R. (2003) DnaSP, DNA polymorphism analyses by the coalescent and other methods, Bioinformatics 19, 2496-2497.

Saiki, R.K. (1990) Amplification of genomic DNA, in: Innis M.A., Gelefland D.H., Snensky J.J., White T.J. (Eds.), PCR Protocols: methods and applications, Academic Press, San Diego, CA, pp. 13-20.

Schmid-Hempel, P. (1998) Parasites in social insects, Princeton, New Jersey.

Tangjingjai, W., Verakalasa, P., Sittipraneed, S., Klinbunga, S., Lekprayoon, C. (2003) Genetic differences between Tropilaelaps clareae and Tropilaelaps koenigerum in Thailand based on ITS and RAPD analyses, Apidologie 34, 514-524.

Thompson, J.D., Higgins, D.G., Gibson, T.J. (1994) CLUSTAL W: improving the sensitivity of progressive multiple sequence alignment through sequence weighting, position-specific gap penalties and weight matrix choice, Nucleic. Acids. Res. 22, 4673-4680.

vanEngelsdorp, D., Evans, J.D., Saegerman, C., Mullin, C., Haubruge, E., et al. (2009) Colony Collapse Disorder: a descriptive study, PLoS ONE 4, e6481.

White, T.J., Bruns, T., Lee, S., Tayler, J. (1990) Ampliffication and direct sequencing of fungal ribosomal RNA genes for phylogenetics, in: Innis M.A., Gelfand D.H., Sninsky J.J., White T.J. (Eds.), PCR protocols, Academic Press, San Diego, pp. 315-322.

Woyke, J. (1994) Mating behaviour of the parasitic honeybee mite Tropilaelaps clareae, Exp. Appl. Acarol. 18, 723-733.

Zeng, Z.J. (2003) Discussion about the hosts of T. clareae, Journal of bee 56, 40-41. 